\title{
Manfaat Penggunaan Media Visual Dalam Menunjang Pembelajaran Pendidikan Jasmani Pada Materi Lompat Jauh
}

\author{
Dicky Edwar Daulay, Joko Priono \\ Jurusan Pendidikan Jasmani Kesehatan dan Rekreasi, Univ.Pembinaan Masyarakat Indonesia Medan \\ dickyedwar89@gmail.com,Priono257@gmail.com
}

\begin{abstract}
Abstrak: Penelitian bertujuan untuk menemukan sejauh mana pemanfaatan media visual dalam menunjang pembelajaran pendidikan jasmani pada materi lompat jauh. Sampel dalam penelitian ini sebanyak 30 orang siswa SMA Negeri 2 Kisaran. Adapun metode penelitian ini adalah penelitian tindakan kelas (Classroom Action Research) yaitu penelitian yang dilakukan oleh guru di kelasnya sendiri melalui refleksi diri bertujuan untuk memperbaiki kinerjanya sehingga hasil belajar siswa meningkat. Untuk memperoleh data dalam penelitian ini maka dilakukan Tes Hasil Belajar 1 yang berbentuk aplikasi teknik dasar lompat jauh gaya pada saat sikap mendarat. Hasil analisis dari data yang terkumpul diperoleh: (1) Data tes awal diperoleh 23 orang siswa $(55,8 \%)$ yang telah mencapai tingkat ketuntasan belajar, sedangkan 7 orang siswa $(44,2 \%)$ belum mencapai tingkat ketuntasan belajar dengan nilai rata-rata hasil belajar siswa adalah 62,4\%. (2) tes hasil belajar 1 di siklus 1 diperoleh peningkatan yaitu 11 orang siswa yang mencapai tingkat ketuntasan belajar dengan persentase sebesar $25 \%$. Secara keseluruhan pada siklus 1 dari 30 orang siswa diperoleh 26 orang siswa $(80,8 \%)$ yang telah mencapai tingkat ketuntasan belajar, sedangkan 4 orang siswa $(19,2 \%)$ belum mencapai tingkat ketuntasan belajar, dengan nilai rata-rata hasil belajar siswa adalah $71,7 \%$. Berdasarkan analisis yang dilakukan dapat dikatakan bahwa dengan penggunaan media visual dapat menunjang pembelajaran pendidikan jasmani pada materi lompat jauh.
\end{abstract}

Kata Kunci: Media pembelajaran, Lompat jauh.

\section{Benefits of Use of Visual Media in Support Learning Jasmani Education in Materials Long Jump Materials}

\begin{abstract}
The research aims to find the extent of the use of visual media in supporting physical education learning on the long jump material. The sample in this study was 30 students of SMA Negeri 2 Kisaran. The research method is Classroom Action Research, namely research conducted by teachers in their class through self-reflection aims to improve performance so that student learning outcomes improve. To obtain data in this study, the Learning Outcomes Test 1 in the form of Basic technical applications of long jump style when landing. The results of the analysis of the data collected were obtained: (1) Initial test data obtained by 23 students (55.8\%) who had reached the level of mastery learning, while 7 students (44.2\%) had not reached the level of mastery learning with an average score the average student learning outcome is 62.4\%. (2) The learning achievement test 1 in cycle 1 obtained an increase of 11 students who reached the level of mastery learning with a percentage of $25 \%$. Overall in the first cycle of 30 students obtained 26 students (80.8\%) who have reached the level of mastery learning, while 4 students (19.2\%) have not reached the level of mastery learning, with an average value of student learning outcomes is $71.7 \%$. Based on the analysis conducted it can be said that the use of visual media can support physical education learning in the long jump material.
\end{abstract}

Keywords: Learning media, Long jump. 


\section{PENDAHULUAN}

Siswa juga dituntut menyelesaikan segala tugas sekolah, yang diperoleh dari kegiatan proses mengajar tersebut kurang menarik, membosankan, materi yang diajarkan bersifat monoton, sehingga hal ini menjadi masalah yang serius untuk membuka jalan penyelesaian baik bagi guru di lingkungan sekolah.Guru sangat berperan dalam membantu perkembangan peserta didik untuk mewujudkan tujuan hidupnya secara optimal Kualitas dan kuantitas pendidikan jasmani sampai saat ini masih tetap merupakan bahan perbincangan sebagai pencerminan dari kondisi pendidikan kita saat ini yang fenomenal dan problematis. Keduanya merupakan sasaran usaha pembaharuan atau reformasi pendidikan nasional. Berapa tidak, kedua masalah tersebut sulit ditangani secara tuntas, sebab terkait dengan varibel lain sebagaimana yang disebutkan di atas. Disamping itu terjadinya krisis multi dimensional yang melanda kehidupan berbangsa, yang sedikit banyak bermuara pada penurunan kualitas pendidikan. Karena itu tidak heran kalau masalah pendidikan tidak pernah tuntas di manapun, bahkan di negara-negara sekalipun.

Tugas guru bukan hanya menyampaikan bahan pelajaran agar dapat diterima serta di internalisasikan oleh anak didik tetapi juga mempunyai peran-peran serta fungsi lain yang bersifat majemuk. Sekali waktu ia juga harus membimbing anak belajar, sekali waktu harus memberi contoh teladan, dan bahkan memimpin murid manakala memang diperlukan. Peran guru sebagai fasilitator adalah menyiapkan kondisi - kondisi lingkungan belajar dan memberikan petunjuk-petunjuk, penyediaan dan pengaturan alat dan fasilitas, agar anak didik mendapat kemudahan dalam pemecahan masalah belajarnya. Apabila seorang guru dapat menerapkan peran-peran proses pembelajaran diatas maka segala kegiatan dalam pembelajaran akan terasa lebih menyenangkan dan lebih bermakna bagi siswa.Melalui perkembangan teknologi pendidikan dan komunikasi yang pesat, maka media dalam pendidikan pun berkembang pesat pula, baik kuantitas maupun kualitasnya.

Jenis media pembelajaran menjadi lebih banyak, diantaranya media visual, media kaset, media film, media video dan media slideMedia sebagai proses sumber informasi bagi anak didik harus memadai dan sesuai dengan tujuan pembelajaran yang akan dicapai, sehingga pendidik/guru dituntut untuk dapat memilih dan menyediakan media yang sesuai dengan kebutuhan sehingga proses belajar dapat terlaksana dengan baik.Penggunaan media tidak hanya membuat proses pembelajaran lebih efisien, tetapi materi pelajaran dapat diserap lebih mendalam. Siswa mungkin sudah memahami suatu permasalahan melalui penjelasan guru, pemahaman itu akan lebih baik lagi jika diperkaya dengan kegiatan melihat, menyentuh, merasakan atau mengalami melalui media. Disamping itu media dapat memperkuat kecintaan dan apresiasi siswa terhadap ilmu pengetahuan dan proses mencari ilmu itu sendiri.

Media adalah kata jamak dari medium, berasal dari bahasa latin yang berarti perantara atau pengantar. Pengertian secara harfiah ini selanjutnya menurunkan berbagai defenisi media seirama dengan perkembangan teknologi dalam pendidikan, seperti yang dikemukakan Soepartono (2000:3), "media adalah sebagai segala bentuk yang dipergunakan untuk memproses penyaluran informasi". Selanjutnya National Education Assosiation (NEA) dalam Soepartono (2000:3) mendefenisikan, "media adalah segala hal yang dapat dimanipulasikan, dilihat, didengar, dibaca, atau dibicarakan beserta pirantinya untuk kegiatan tersebut".

Media juga sering disebut juga sebagai perangkat lunak yang bukan saja memuat pesan atau bahan ajar untuk disalurkan melalui alat tertentu, tetapi juga dapat merangsang fikiran, perasaan dan kemauan siswa sehingga dapat mendorong terjadinya proses belajar pada dirinya oleh karenanya media harus digunakan secara kreatif dalam arti guru harus menyiapkan dan merancang dengan tepat agar memungkinkan siswa belajar lebih banyak, mencamkan lebih baik apa yang dipelajari dan meningkatkan performa mereka sesuai dengan tujuan yang ingin dicapai. Disinilah guru dituntut lebih berhati-hati dalam memilih dan menetapkan media yang tepat dalam proses pembelajaran.

Manfaat media di identifikasi oleh Kemp dan Dayton dalam (Soepartono,2000:15) sebagai berikut: penyampaian materi pelajaran dapat diseragamkan, proses instruksional menjadi lebih menarik, proses belajar siswa menjadi lebih interaktif, jumlah waktu belajar mengajar dapat dikurangi, kualitas belajar siswa dapat ditingkatkan, proses belajar dapatt terjadi dimana saja dan kapan saja, sikap positif siswa terhadap materi belajar maupun terhadap proses belajar dapat ditingkatkan, peran guru dapat berubah kearah yang lebih positif dan produktif. 
Pendidikan jasmani merupakan proses interaksi antara peserta didik dan lingkungan yang dikelola melalui aktifitas jasmani secara sistematik menuju pertumbuhan fisik anak yang baik, perkembangan mental, emosi, dan sosial yang serasi, selaras dan seimbang. Menurut Sunarno (2005:12) pembelajaran pendidikan jasmani adalah :"sebagai suatu proses sudah barang tentu harus dapat mengembangkan dan menjawab beberapa persoalan yang mendasar sebagai proses interaksi edukatif yang meliputi: 1) Kemana proses tersebut akan diarahkan. 2) Apa yang harus dibahas dalam proses tersebut. 3) Bagaimana cara melakukannya. 4) Bagaimana cara mengetahui berhasil tidaknya proses tersebut. 5) Dalam keadaan gimana. 6) Siapa yang menyelenggarakan / menyampaikan. 7. Kepada siapa disampaikan / ditujukan.

Belajar adalah "key term", istilah kunci yang peling vital dalam setiap usaha pendidikan, sehingga tanpa belajar sesungguhnya tak pernah ada pendidikan. Perubahan dan kemampuan untuk berubah merupakan batasan makna yang terkandung dalam belajar. Secara psikologis belajar merupakan suatu proses perubahan yaitu perubahan tingkah laku sebagai hasil interaksi dengan lingkungannya dalam memenuhi kebutuhan hidupnya. Perubahan-perubahan tersebut akan nyata dalam seluruh aspek tingkah laku.

Perubahan itu dapat berupa pengembangan pengetahuan, sikap, keterampilan yang diharapkan mampu memecahkan masalah atau tuntutan hidupnya. Karena itu seseorang dikatakan belajar bila diasumsikan di dalam diri orang tersebut telah terjadi proses yang mengakibatkan perubahan tingkah laku. Kegiatan dan usaha untuk mencapai perubahan tingkah laku merupakan proses belajar sedangkan perubahan tingkah laku merupakan hasil belajar. Dari kutipan diatas dapat disimpulkan bahwa, belajar adalah suatu proses yang terjadi dalam diri seseorang yang melibatkan kegiatan atau proses berfikir dan terjadi melalui pengalaman-pengalaman belajar dan melalui reaksi - reaksi terhadap lingkungan dimana individu berada, sehingga terjadi perubahan tingkah laku dalam diri individu tersebut.

Bagi siswa itu sendiri hasil belajar dapat memotivasi siswa untuk mau belajar lebih giat lagi, karena fungsi hasil belajar bukan saja untuk mengetahui sejauh mana kemajuan siswa setelah menyelesaikan suatu aktifitas, tapi yang penting adalah sebagai alat untuk memotivasi setiap siswa agar lebih giat belajar secara individu maupun kelompok. Siswa yang mengetahui hasil belajarnya rendah akan terdorong untuk belajar lebih giat lagi. Sementara siswa yang mengetahui hasil belajarnya sudah mengalami kemajuan, maka ia akan berusaha mempertahankannya atau bahkan meningkatkan intensitas belajarnya guna mendapatkan prestasi belajar yang baik dikemudian hari. Dengan demikian prestasi belajar merupakan suatu kebutuhan yang memunculkan motivasi untuk belajar.

Berdasarkan teknik dalam olahraga lompat jauh terdapat beberapa macam gaya yang biasanya digunakan, terutama oleh atlet profesional. Gaya yang digunakan tersebut merupakan gaya yang telah terbukti dapat memberikan hasil lompatan yang maksimal sesuai dengan kondisi fisik dan kemampuan atletnya. Beberapa macam gaya yang digunakan tersebut antara lain adalah 1) Gaya Jongkok, 2) Gaya Lenting, 3) Gaya Berjalan di Udara. Perbedaan dari ketiga gaya lompat jauh tersebut adalah pada posisi tubuh pada saat melayang di udara (Syarifuddin, $1992: 60$ ).

Gilang (2007:60) mengemukakan bahwa: "untuk dapat melakukan lompatan yang baik harus memiliki komponen berikut: 1) awalan yang makin meningkat kecepatannya, teratur, terarah, dan mencapai kecepatan maksimal pada saat mencapai papan tolakan, 2) gerakan pada saat menolak, 3) gerakan saat melayang dan 4) gerakan waktu mendarat".

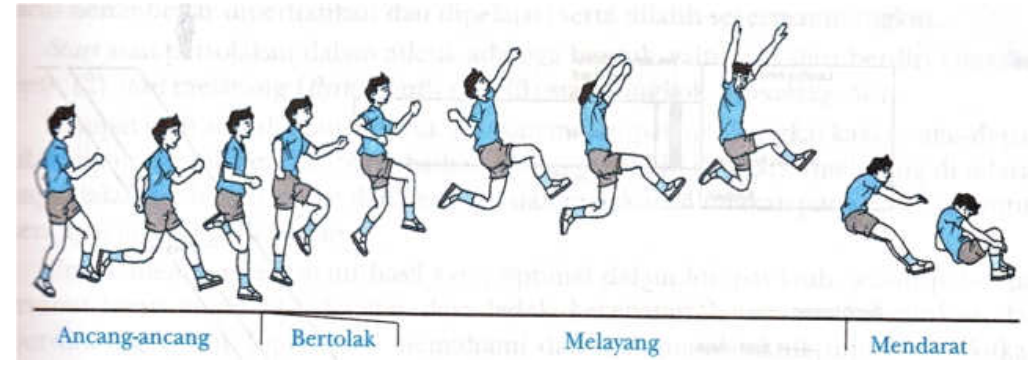

Gambar 1. Rangkaian Gerakan Lompat Jauh (Gilang, 2007:61) 
Pada saat melakukan tolakan yang perlu di perhatikan antara lain adalah bersama dengan menolak kaki tolakan, kaki belakang di ayun sekuat-kuatnya ke atas depan lurus dibantu dengan mengayunkan kedua tangan dari belakang ke depan atas. Untuk mempertinggi lompatan yang cukup tanpa mengorbankan kecepatan maka sudut badan pada waktu menumpu tidak telalu condong ke depan seperti pada lompat tinggi karena bisa menghambat jauhnya lompatan.

Adisasmita (1992:68) mengungkapkan bahwa: "Gerakan sikap tubuh di udara (waktu melayang) inilah yang disebut gaya lompatan dalam lompat jauh. Waktu melayang di udara dapat dilakukan berbagai gaya lompatan sesuai dengan keterampilan masing-masing pelompat. Gaya lompat jauh yang dikenal adalah 1) Gaya jongkok, 2) Gaya lenting, dan 3) Gaya berjalan di udara". Namun gaya yang dipergunakan pada penelitian ini adalah gaya jongkok.

\section{METODE}

Penelitian ini dilaksanakan pada bulan April tahun 2020. Adapun subjek dalam penelitian ini adalah seluruh siswa kelas XI-A SMA Negeri 2 Kisaran dengan jumlah 30 orang siswa. Metode penelitian ini adalah Penelitian Tindakan Kelas (Classroom Action Research) yaitu penelitian yang dilakukan oleh guru di kelasnya sendiri melalui refleksi diri dengan tujuan untuk memperbaiki kinerjanya sehingga hasil belajar siswa meningkat (Aqib, 2009:3). Pendekatan yang digunakan adalah pendekatan kualitatif yang berguna untuk mengungkapkan kesulitan belajar siswa dalam proses pembelajaran pendidikan jasmani serta cara mengatasi kesulitan-kesulitan tersebut sebagai upaya untuk memperbaiki hasil belajar siswa pada materi tersebut. Sesuai dengan jenis penelitian ini, yaitu penelitian tindakan kelas maka penelitian ini dilakukan menjadi beberapa tahap yang berupa suatu siklus. Adapun data penelitian diperoleh dari performa siswa yang dinilai menggunakan instrumen penilaian tes hasil belajar khusus teknik mendarat.

\section{HASIL DAN PEMBAHASAN}

Didalam pembelajaran melalui penggunaan media visual dapat menunjang pembelajaran pendidikan jasmani khusus pada teknik mendarat dalam lompat jauh khususnya pada saat melakukan pendaratan. Pada saat melakukan pendaratan cukup baik yaitu sebesar 80,8\% dan hasil persentase tersebut telah melampaui kriteria ketuntasan minimal yang ingin dicapai pada pembelajaran ini. Salah satu faktor yang dapat mendukung keberhasilan tersebut adalah penggunaan media visual dalam penggunaan pembelajaran pendidikan jasmani.

Penggunaan media visual dalam menunjang pembelajaran pendidikan jasmani. Dalam pembelajaran ini siswa diajarkan memahami bagaimana cara melakukan gerakan sebenarnya dari lompat jauh dengan membuka daya penalaran siswa melalui alat infokus pada media visual sehingga pembalajaran dapat efektif lebih menyenangkan serta lebih bermakna.

Media visual merupakan salah satu media pembelajaran yang dapat membangkitkan ketertarikan dan daya penalaran siswa terhadap materi yang disampaikan guru dapat menerapkannya dengan maksimal. Dan akhirnya apa yang diharapkan dan diyakini telah dapat meningkatkan hasil belajar yang lebih baik.

$19,2 \%$

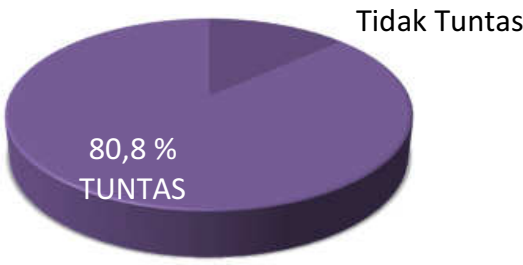

Tidak Tuntas

QTuntas

Gambar 2. Persentase Ketuntasan Pada Tes Hasil Belajar Materi Lompat Jauh 
Pada saat pemberian materi lompat jauh gaya jongkok khususnya teknik pendaratan melalui alat media visual,siswa sangat antusias dan aktif dalam memperhatikan penjelasan yang diajarkan oleh guru. Siswa dapat menganalisis dari materi lompat jauh yang diberikan guru,sehingga dalam pelaksanaan praktek di lapangan kebanyakan siswa dapat dengan baik melakukan teknik lompat jauh. Khususnya pada saat melakukan pendaratan,sikap badan,arah badan dan posisi badan benar - benar sesuai dengan yang sebenarnya. Dengan demikian, proses pembelajaran media visual yang diharapkan dapat berjalan dengan sukses.

\section{SIMPULAN}

Berdasarkan hasil penelitian ditarik kesimpulan yaitu : Dari hasil belajar siswa sebelum diberi perlakuan (data awal) bahwa kemampuan siswa Dengan nilai rata-rata hasil belajar siswa sangat baik. Kemampuan siswa dalam menyelesaikan tes hasil belajar secara klasikal sudah meningkat. Dari 30 siswa terdapat 7 orang siswa yang telah mencapai tingkat ketuntasan belajar dengan persentase $25 \%$. Sehingga pada siklus I, dari 30 orang siswa ada 23 siswa $(81,8 \%)$ yang telah mencapai tingkat ketuntasan belajar sedangkan 7 siswa $(18.2 \%)$ belum mencapai tingkat ketuntasan belajar. Dengan nilai rata-rata hasil belajar siswa adalah $71,7 \%$. Dengan demikian, penggunaan media visual pada cabang atletik khusus lompat jauh gaya jongkok pada tekhnik pendaratan dapat menunjang dalam pembelajaran jasmani

\section{DAFTAR PUSTAKA}

Adisasmita. 1992. Olahraga Pilihan Atletik. Jakarta: Departemen Pendidikan dan Kebudayaan Direktorat jenderal Pendidikan Tinggi Proyek Pembinaan Tenaga Kependidikan.

Agung, Sunarno. 2005. Evaluasi Hasil Belajar Pendidikan Jasmani. Medan: Diktat Perkuliahan FIK Universitas Negeri Medan.

Akatinah. 2005. Pengaruh latihan awalan 9 dan 11 langkah terhadap hasil lompat jauh gaya jongkok pada siswa putri SD negeri Banjarejo Kecamatan Boja Kabupaten Kendal Tahun Pelajaran 2004 / 2005. Semarang.

Bernhard, Gunther. 1993. Atletik. Semarang: Dahara Prize.

Dimyanti dan Mudjiono. 2006. Belajar dan Pembelajaran. Jakarta: Penerbit PT.Gramedia Pustaka Utama.

Edward, dkk. 2003. Belajar dan Pembelajaran. Medan: Diktat Perkuliahan Mahasiswa Universitas Negeri Medan.

Eko Purwono. 2010. Upaya Meningkatkan Hasil Belajar Siswa Menggunakan accelerated learning melalui pendekatan SAVI (somatic-auditori-visual-intelektual) pada materi lompat jauh di kelas X SMA Negeri 1 Kualuh Selatan T.A 2010/2011. FIK Unimed.

Fuad Ihsan. 2005. Dasar- Dasar Pendidikan. Jakarta: PT. Rineka Cipta.

Helly P. 2008. Effective Teaching. Bandung: PT. Gramedia Karya.

Husdarta, dkk. 2000. Belajar dan Pembelajaran. Jakarta: Departemen Pendidikan Nasional Direktorat Jenderal Pendidikan Dasar dan Menengah Bagian Proyek Penataran Guru SLTP Setara D-III.

Muslikah. 2010. Sukses Profesi Guru Dengan Penelitian Tindakan Kelas. Yogyakarta: Perpustakaan Nasional. 
Nadisah. 1992. Pengembangan Kurikulum Pendidikan Jasmani dan Kesehatan. Jakarta: Departemen Pendidikan dan Kebudayaan Direktorat Jenderal Pendidikan Tinggi Proyek Pembinaan Tenaga Kependidikan.

Rusli, dkk. 2004. Supervisi Pedidikan Jasmani. Depdikbud: Direktorat Jenderal Pendidikan Dasar dan Menengah.

Suherman, dkk. 2000. Atletik. Jakarta: Departemen Pendidikan Nasional Direktorat Jenderal Pendidikan Dasar dan Menengah Bagian Proyek Penataran Guru SLTP Setara D-III.

Syarifuddin. 1992. Atletik. Jakarta: Departemen Pendidikan dan Kebudayaan Direktorat Jenderal Pendidikan Tinggi Proyek Pembinaan Tenaga Kependidikan.

Soepartono. 2000. Media Pembelajaran. Jakarta: Departemen Pendidikan Nasional Direktorat Jenderal Pendidikan Dasar dan Menengah Bagian Proyek Penataran Guru SLTP Setara D-III.

Suryosubroto B. 2009. Proses Belajar Mengajar di Sekolah. Jakarta: Rineka Cipta.

Syah, M. 2003. Psikologi Belajar. Jakarta: Radja Grafindo.

Winendra Adi, dkk. 2008. Seri Olahraga Atletik. Yogyakarta: Pustaka Insan Madani. 